\title{
Obstructing pathology of the upper airway in a post-NAP4 world: time to wake up to its optimal management
}

\author{
J. Adam Law, MD $\odot$ Ian R. Morris, MD • Gemma Malpas, MBChB, FANZCA
}

Received: 29 May 2017/ Accepted: 5 July 2017/Published online: 10 July 2017

(c) Canadian Anesthesiologists' Society 2017

Patients with obstructing airway pathology (OAP) requiring airway management are amongst the most challenging of cases. They are also substantially overrepresented in large-scale studies of morbidity and mortality related to airway management. The $4^{\text {th }}$ National Audit Project (NAP4) published in the United Kingdom in 2011 comprised data from September 2008 to August 2009 on airway-related death, brain damage, need for emergency surgical airway, and admission to or prolonged stay in the intensive care unit. Seventy-two (39\%) of the 184 reported cases occurred in patients with an acute or chronic disease process in the head, neck, or trachea, and $70 \%$ of these cases involved OAP. ${ }^{1}$ A decade earlier, a key message from the 1997 National Confidential Enquiry on Perioperative Deaths (NCEPOD) in the UK (reporting from April 1996 to March 1997) stated that "the management of the obstructed airway gave cause for concern". 2

Why the apparent overrepresentation of morbidity relating to the management of OAP, and why the continued occurrence of the same issues from one decade to the next? Will any improvement occur a decade after NAP4?

Following their analysis of the submitted cases, the authors of the NAP4 chapter on head and neck pathology identified areas where management was suboptimal, as did the previous NCEPOD. This editorial reviews opportunities for improvement in airway management-

J. A. Law, MD $(\varangle)$. I. R. Morris, MD .

G. Malpas, MBChB, FANZCA

Department of Anesthesia, Pain Management and Perioperative Medicine, Dalhousie University, QEII Health Sciences Centre, Halifax Infirmary Site, 1796 Summer Street, Halifax,

NS B3H 3A7, Canada

e-mail: j.law@dal.ca i.e., evaluation, decision-making, and implementation, for the patient presenting with OAP.

\section{Evaluation of the patient with obstructing airway pathology}

One theme to emerge from both NAP4 and NCEPOD is the need to perform a thorough airway evaluation-if the patient's symptoms allow. ${ }^{1,2}$ Although criticized for its poor positive predictive value ${ }^{3,4}$ (i.e., correctly predicting those patients with a difficult airway), there are two reasons why the standard airway examination must be carefully performed in the patient presenting with OAP. First, the underlying obstructing pathology may secondarily impact standard predictors of difficult direct or video laryngoscopy (e.g., an obstructing infective process may affect mouth opening due to trismus). Second, adding de novo predictors of difficulty to preexisting predictors of difficult laryngoscopy or difficult face mask ventilation in the patient with OAP may further lower the threshold for choosing an awake approach to securing the airway.

Obstructing airway pathology can occur in the pharynx; in the supraglottic, glottic, and subglottic larynx; and in the trachea. Regardless of location, the standard airway exam can fall short of delineating the exact location(s) and nature of the OAP or the extent to which it causes narrowing or distortion of the airway lumen. Thus, for a suspected or known OAP, the standard exam should be enhanced by a nasal endoscopic evaluation of the upper airway under local anesthesia; for subglottic and tracheal disease, computed tomography (CT) or magnetic resonance imaging (MRI) should be reviewed. Rosenblatt et al. studied 138 patients who presented for upper airway surgery with pathology in a variety of locations. ${ }^{5}$ All 
patients were evaluated by history and a standard airway examination, and a decision was made on how to proceed with airway management. A preoperative endoscopic airway evaluation (PEAE) was then undertaken nasally. The epiglottis, vallecula, vocal cords, and both pyriform sinuses were visualized. Following PEAE, 28 (64\%) of the 44 patients who were planned for an awake approach were subsequently deemed safe for airway management after the induction of general anesthesia. More importantly, in our view, following PEAE, 8 (9\%) of the 94 patients who were to receive airway management after induction in fact received awake intubation. Nasal endoscopy is often performed by otolaryngologists as part of their patient evaluation, but their focus differs from that of an anesthesiologist, and the exam may have been performed at an earlier time. Nasal endoscopy performed immediately before airway intervention can help determine if impediments exist with planned video or direct laryngoscope blade placement (e.g., a base-of-tongue lesion or vallecular cyst), laryngeal visualization (e.g., extensive supraglottic edema or a displaced larynx), flexible bronchoscope or tracheal tube passage (e.g., severely narrowed laryngeal aperture), face mask ventilation, or use of an supraglottic device. Awake video laryngoscopy can also be used to enhance the airway evaluation, with the proviso that base-of-tongue pathology may preclude optimal blade placement or could be traumatized during the procedure.

Most anesthesiologists are familiar with the anatomy of the upper airway as viewed through the endoscope. The same cannot be said regarding the preoperative assessment of airway lesions on CT scans or MRIs. Such studies are best reviewed with a radiologist or the patient's attending surgeon to aid in the interpretation of the location and extent of obstructing pathology. In this issue of the Journal, El-Boghdadly et al. report the use of imaging software to convert helical CT scans to a three-dimensional (3D) virtual endoscopy format that can be used to deliver a "fly through" intraluminal view of the supraglottic, glottic, and subglottic anatomy, similar to that obtained during flexible bronchoscopy. ${ }^{6}$ They assessed the utility of the imaging by asking a convenience sample of their colleagues to indicate their management of ten scenarios, each comprised of a brief clinical vignette and a standard helical CT scan. The 3D virtual endoscopy imaging was added at a later date, and their management choices were reassessed. Their subsequent management became more cautious.

When feasible, the standard airway evaluation should be enhanced by nasal endoscopy or a review of CT or MRI scans in all patients with a known or suspected OAP, regardless of their presenting signs or symptoms. Through respiratory muscle conditioning, the patient with a slowly growing tumour may be minimally symptomatic despite advanced obstructing disease. Similarly, in a patient stridulous from more acutely obstructing laryngeal disease, the stridor may become less evident as respiratory muscle fatigue develops. Occasionally, the patient requiring urgent tracheal intubation for advanced and symptomatic disease may have to forego some components of an enhanced airway evaluation because time does not permit or because of an inability to tolerate the supine (or even semi-reclined) position needed for CT or MRI scanning. Nasal endoscopic examination may still be possible. In this circumstance, the lack of a full enhanced airway evaluation must be considered in planning airway management.

\section{Synthesizing a plan from the information obtained from the airway evaluation}

The results of the standard and enhanced airway evaluations are used to arrive at the safest primary and backup approaches to securing the airway. A thorough evaluation of the OAP patient may in fact indicate that airway management can safely proceed after the routine intravenous induction of general anesthesia, facilitated by neuromuscular blockade. This would presuppose that, despite the obstructing pathology, evaluation indicates little anticipated difficulty with direct or video laryngoscopy (i.e., blade placement or subsequent laryngeal exposure), tracheal intubation, face mask ventilation, extraglottic device placement, or physiologic issues such as a full stomach or anticipated intolerance of apnea. ${ }^{7,8}$ In the Rosenblatt study, 114 of the 138 (83\%) patients presenting for airway surgery-most of whom had obstructing lesions-were safely managed after induction. Notwithstanding, it must be emphasized that enhanced airway evaluation with preoperative nasal endoscopy minimized the role of guesswork in achieving this good outcome.

At the other extreme, enhanced airway evaluation may indicate that awake tracheostomy is the safest way to secure the airway. During nasal endoscopy, this approach would be indicated by a significantly narrowed laryngeal aperture or pathology that renders the larynx unrecognizable (i.e., significantly displaced or adversely angulated).

Both awake transoral or transnasal intubation ${ }^{9}$ and tracheal intubation following inhalational induction of general anesthesia ${ }^{10}$ have been advocated for less extreme but still difficult situations identified at nasopharyngoscopy. Both techniques have been used successfully in this population, but as NAP4 records, failures have also occurred. ${ }^{1}$ Unfortunately, NAP4, 
NCEPOD, or closed claims ${ }^{11}$ studies are unable to supply denominator data in the OAP population, making it difficult to make a direct comparison between the failure rate of awake oral or nasal intubation and that following inhalational induction.

Inhalational induction obviates the need for patient cooperation and, once achieved, will theoretically allow for direct or video laryngoscopy and primary passage of an endotracheal tube (ETT). Potential advantages include the maintenance of spontaneous ventilation and rapid offset of hypnosis if difficulties are encountered in securing the airway. Risks of inhalational induction include adverse effects on airway tone and patency, ${ }^{12,13}$ which may make the induction difficult and prolonged when combined with OAP. Furthermore, if airway patency is lost, the apnea associated with complete obstruction will prevent offgassing of the volatile agent, thus obviating its putative safety benefit of rapid emergence. In the 16 cases of inhalational induction in the NAP4 report, the airway became compromised in 12 , with the loss of spontaneous ventilation in $11 .{ }^{1}$ Inhalational induction of general anesthesia in the adult patient with OAP should generally be reserved as an option for patients who are unable to cooperate with an awake approach.

Awake oral or nasal intubation allows the theoretical safety benefit of having the patient maintain gas exchange, airway patency, and airway protection while the airway is being secured. In addition, if the flexible endoscope is used, it will allow navigation around obstructing lesions at the base of the tongue and will act as a stylet to help guide the ETT through the larynx and down the trachea. Conversely, optimal topical airway anesthesia may be difficult to obtain with some causes of OAP, and passage of an endoscope through a narrowed laryngeal aperture may be difficult or poorly tolerated by the awake patient. Furthermore, both local anesthesia itself ${ }^{14-16}$ and concomitant sedation ${ }^{17}$ have been reported to cause complete loss of airway patency during attempted awake intubation. The NAP4 data on awake oral or nasal intubation are difficult to interpret because the 23 recorded uses of flexible bronchoscopic intubation included its use in both anesthetized and awake patients. Failure occurred in 14 cases, only four of which were in awake patients. ${ }^{1}$

Clearly then, both awake intubation and inhalational induction can fail in the OAP population, although the rate of occurrence is unknown. This emphasizes the need to include a backup plan in case of failure to secure the airway while oxygenation is maintained or when encountering a "cannot intubate, cannot oxygenate" (CICO) situation. The NAP4 was clear that there were cases in the OAP population where multiple attempts at tracheal intubation led to a CICO situation. This implies the need to minimize attempts with any one technique so as to engage an alternative plan (e.g., proceeding with awake tracheostomy after failed awake oral or nasal intubation) before encountering a CICO situation. The plan for CICO is even more crucial as it is more likely to occur in the OAP population. The chosen backup plan for CICO must be truly viable, as opposed to performing a rapid emergency surgical airway in an obese patient with an indurated or previously irradiated neck or "crashing" onto extracorporeal membrane oxygenation (ECMO) in an apneic patient. The absence of a viable plan for CICO should elevate consideration of awake tracheostomy under local anesthesia as the primary plan or, very rarely, first establishing ECMO under local anesthesia.

Optimal management of the patient with mid-tracheal obstructing pathology is controversial. Maintenance of spontaneous ventilation has been advocated, whereas others recommend intravenous induction with administration of neuromuscular blockade. ${ }^{18}$

\section{Implementing the plan for securing the airway in the patient with OAP}

With the information gleaned from standard and enhanced airway evaluations, a rational plan can be made for safely proceeding with airway management. Expert implementation of the plan is crucial for the patient with OAP. Interestingly, the NAP4 panel of expert reviewers deemed only $30 \%$ of the reported head and neck cases to be poorly managed, ${ }^{1}$ which suggests that, despite a rational plan, things can go wrong during implementation. This has a number of implications. First, for the emergency patient, the airway should be secured early-i.e., before complete obstruction is imminent and while patient cooperation allows the option of a methodical approach to awake oral or nasal intubation or awake tracheostomy. Second, for both emergency and elective surgical patients with a tenuous airway - as losing the airway is always possible during intubation attempts-full equipment and personnel should be present for all the primary and alternative intubation and CICO plans so as to facilitate smooth and rapid transitions if needed. ${ }^{19}$ If an emergency cricothyrotomy is a backup plan, the location of the cricothyroid membrane (CTM) should be determined and marked beforehand, recognizing that existing studies indicate poor success at identification of the CTM by palpation alone..$^{20-22}$ Thus, if time permits, ultrasound should be used to locate the CTM. ${ }^{23}$ The surgical safety briefing should include the planned primary and alternative intubation techniques as well as the plan for a CICO situation. Triggers should be specified for moving on to the alternative intubation or CICO plan. Ideally, all personnel in the room should be empowered to verbalize when those 
triggers are tripped to help avoid inappropriate fixation on one technique.

For awake airway interventions (i.e., awake tracheostomy and awake oral or nasal intubation) in the patient with OAP, positioning the patient in a semirecumbent or sitting position will increase comfort and thus their cooperation with the procedure. Heliox, a low-density mixture of helium and oxygen, will often help the work of breathing, again favourably impacting patient comfort and cooperation. Supplemental oxygen can be delivered, although, when used along with Heliox, it will dilute the latter and reduce its effectiveness. End-tidal $\mathrm{CO}_{2}$ monitoring will help confirm ongoing gas exchange during the awake intervention.

There are two reasons to omit sedation in the awake patient with a tenuous airway. First, some agents have adverse effects on airway tone or respiratory effort. ${ }^{12}$ Second, a patient who can briskly comply with commands is helpful for the application of topical airway anesthesia and subsequent flexible endoscopic intubation. Asking the patient to inhale while advancing a flexible endoscope will help elevate the epiglottis, while asking the patient to sniff is effective in abducting the vocal folds to facilitate endoscope or tracheal tube passage through the glottis. In the patient with significant supraglottic edema, often the only indicator of the location of the glottic opening is movement of edematous tissues with respiration and bubbles appearing on expiration. Calm and confident reassurance should be substituted for pharmacologic sedation.

The patient with a compromised laryngeal aperture is often best managed with awake tracheostomy; however, if awake oral or nasal endoscopic intubation has been elected, attention must be paid to details of endoscope and ETT passage. Use of a smaller diameter endoscope and ETT may be advantageous, although potentially at the cost of endoscope controllability. The patient should be warned that they may transiently not be able to breathe during passage of the endoscope and ETT. It may be helpful to have the patient first do a brief "trial of apnea" to prove that they can tolerate a short breath-hold. Passage of the endoscope and ETT, and the subsequent removal of the endoscope from the ETT, should be expeditious. Alternatively, awake video laryngoscopy can be used in the topically anesthetized patient with a compromised laryngeal aperture in order to facilitate primary passage of a small ETT, sparing the potentially poorly tolerated step of endoscope passage. A recent report has detailed the successful use of a new 2.4-mm internal diameter, 40-cm long cuffed ETT in conjunction with the Ventrain ${ }^{\circledR}$ manually operated ejector ventilator (Ventinova Medical B.V., Eindhoven, the Netherlands) ${ }^{24,25}$ in a series of surgical patients, some with severely compromised laryngeal apertures. ${ }^{26}$ This combination holds the promise of potentially sparing some patients the need for awake tracheostomy, although additional studies are required.

Finally, if the standard and enhanced airway evaluation suggests that intravenous induction with neuromuscular blockade is justified, full preparations should still be in place in case difficulty is encountered. This includes equipment for primary and alternative intubation techniques, a supraglottic airway sized for the patient, attention to preoxygenation, and delivery of apneic oxygenation during attempts at laryngoscopy and tracheal intubation. $^{27,28}$ As always, the CTM should be identified and marked, equipment for emergency surgical airway should be available, and there should be an individual designated to proceed rapidly with a surgical airway, if required.

Regardless of the chosen primary technique, expertise in its execution is vital to the patient with OAP. Anesthesiologists should seek (and not avoid) opportunities to perform awake oral or nasal intubation in lower acuity situations in order to attain and maintain expertise in these procedures. Subtleties of maximizing patient comfort and achieving a successful technique can only be gleaned through experience.

\section{Enhancing the airway evaluation: What must happen on a system level?}

As the first and vital step in dealing with OAP, the enhanced airway evaluation requires procedures and skills not regularly used by the average anesthesiologist. Nasal endoscopy can be performed with dedicated nasopharyngoscopes or other small-calibre flexible endoscopes. Topical anesthesia of the nasal mucosa is easy to attain. In our institution, anesthesiology trainees typically perform about 100 nasopharyngoscopies during a one-month rotation under the supervision of a subspecialty airway otolaryngologist, and they must be "signed off" on ten observed procedures as a required training experience. Upon informal inquiry, our trainees rate this experience highly. As competency-based anesthesia residencies become the norm, perhaps strong consideration should be given to making this procedure a core competency.

And what of 3D virtual endoscopy of the airway? How accessible is this technology to the average clinician? To find out, we downloaded a trial version of the OsiriX (Pixmeo SARL, Bernex, Switzerland) software that ElBoghdadly et al. describe in the Methods section of their study. ${ }^{6}$ We then set about obtaining Digital Imaging and Communications in Medicine (DICOM) data of anonymized helical CT images, keeping a close tally of the expended time and effort. After 46 min of telephone 
time during four phone calls to three departments and 24 email exchanges with five different individuals over three days, we did obtain a DICOM file compatible with the OsiriX software. Unfortunately, the free trial version of the software would not support the "3D endoscopy" function needed for the fly-through viewing described in the ElBoghdadly study. We emailed the company to confirm this but received no reply - that's where our efforts ceased. With or without use of this potentially helpful technology, if time permits, it is likely a good practice to review any recent CT scans or MRIs of OAP patients with a radiologist or the attending surgeon.

\section{Conclusion}

As outlined in NAP4 and the NCEPOD, the patient presenting with OAP is at risk during the airway management process. Nevertheless, this risk can be mitigated by enhancing the standard airway evaluation of these patients with additional investigations such as diagnostic nasopharyngoscopy or CT and MRI imaging. The anesthesiologist and the attending surgeon can use this information to engage in a rational discussion and arrive at mutually agreed upon primary and backup plans for securing the airway and for anesthetic management of a shared airway case. Hopefully, with attention to these factors, there will be noticeable improvement in the next morbidity and mortality report related to airway management of the OAP patient.

\section{Les pathologies obstructives des voies aériennes supérieures dans un monde post-NAP4 : il est temps de les prendre en charge de façon optimale}

Les patients atteints de pathologie obstructive des voies aériennes et nécessitant une prise en charge des voies aériennes comptent parmi les cas les plus difficiles. Ils sont également largement surreprésentés dans les études de grande envergure portant sur la morbidité et la mortalité liées à la prise en charge des voies aériennes. Le $4{ }^{\text {ème }}$ projet national d'audit (NAP4), publié en 2011 au Royaume-Uni (R.-U.), présentait des données recueillies sur les cas rapportés entre septembre 2008 et août 2009 examinant les décès, les lésions cérébrales, le recours aux techniques chirurgicales de prise en charge des voies aériennes d'urgence et les cas d'admission ou de séjour prolongé à l'unité de soins intensifs liés à des complications au niveau des voies aériennes. Soixante-douze (39\%) des 184 cas rapportés concernaient des patients souffrant d'un processus pathologique aigu ou chronique au niveau de la tête, du cou ou de la trachée, et une pathologie obstructive des voies aériennes a été documentée dans $70 \%$ de ces cas. ${ }^{1}$ Dix ans plus tôt, un message clé émanant de l'Enquête confidentielle nationale sur les décès périopératoires de 1997 (1997 National Confidential Enquiry on Perioperative Deaths (NCEPOD)) au R.-U. (rapportant les cas observés entre avril 1996 et mars 1997) déclarait que «la prise en charge des voies aériennes obstruées est une source d'inquiétude ». ${ }^{2}$

Pourquoi y a-t-il une apparente surreprésentation de la morbidité liée à la prise en charge des pathologies obstructives des voies aériennes, et pourquoi les mêmes problèmes sont-ils constamment observés d'une décennie à l'autre? Assisterons-nous à un quelconque progrès dix ans après le NAP4?

Suite à leur analyse des cas soumis, les auteurs du chapitre du NAP4 sur les pathologies de la tête et du cou ont identifié les domaines dans lesquels la prise en charge était sous-optimale, tout comme l'avait précédemment fait la NCEPOD. Cet éditorial passe en revue les possibilités d'améliorations dans la prise en charge des voies aériennes - soit l'évaluation, la prise de décision et la mise en œuvre, chez les patients présentant une pathologie obstructive des voies aériennes.

\section{L'évaluation du patient atteint de pathologie obstructive des voies aériennes}

Un thème récurrent tant dans le NAP4 que la NCEPOD était le besoin de réaliser une évaluation détaillée des voies aériennes - si les symptômes du patient le permettent. ${ }^{1,2}$ Bien que critiqué en raison de sa valeur prédictive médiocre $^{3,4}$ (c.-à-d. la prédiction exacte des patients allant présenter des voies aériennes difficiles), deux raisons justifient la réalisation d'un examen standard minutieux des voies aériennes chez un patient atteint de pathologie obstructive des voies aériennes. En premier lieu, la pathologie obstructive sous-jacente pourrait avoir un impact sur les prédicteurs standard de laryngoscopie directe ou de vidéolaryngoscopie difficile (par ex., un processus infectieux obstructif pourrait affecter l'ouverture de la bouche en raison d'un trismus). Deuxièmement, l'ajout de nouveaux prédicteurs de difficulté aux prédicteurs préexistants de laryngoscopie difficile ou de ventilation au masque difficile chez le patient souffrant de pathologie obstructive des voies aériennes pourrait faire augmenter encore plus la probabilité du choix d'une approche éveillée pour l'intubation. 
Les pathologies obstructives des voies aériennes peuvent survenir au niveau du pharynx, du larynx supraglottique, glottique et sous-glottique, et de la trachée. Indépendamment de leur emplacement, il est possible qu'un examen standard ne parvienne pas à déterminer le ou les emplacement(s) exact(s) et la nature de la pathologie obstructive des voies aériennes ou la mesure dans laquelle cette pathologie rétrécit ou déforme la lumière des voies aériennes. Par conséquent, quand il y a suspicion ou connaissance de pathologie obstructive des voies aériennes, l'examen standard devrait être étendu pour inclure une évaluation endoscopique nasale des voies aériennes supérieures sous anesthésie locale; en cas de maladie sous-glottique ou trachéale, il convient d'obtenir des images de tomodensitométrie ou d'imagerie par résonance magnétique (IRM). Rosenblatt et coll. ont étudié 138 patients se présentant pour une chirurgie des voies aériennes supérieures et atteints de pathologies localisées à divers endroits. ${ }^{5}$ Tous les patients ont été évalués selon leurs antécédents et un examen standard des voies aériennes a été réalisé, puis la décision quant à la façon de prendre en charge les voies aériennes a été prise. Une évaluation endoscopique préopératoire des voies aériennes a ensuite été réalisée par voie nasale. L'épiglotte, la vallécule, les cordes vocales et les deux sinus piriformes ont été visualisés. Suite à l'examen préopératoire endoscopique, il a été jugé que 28 (64\%) des 44 patients qui devaient subir une approche éveillée ne couraient pas de risque supplémentaire pour la prise en charge des voies aériennes après l'induction de l'anesthésie générale. Mais, ce qui est plus important encore, selon nous, c'est qu'après cet examen préopératoire, $8(9 \%)$ des 94 patients qui auraient dû être intubés après induction standard ont finalement été intubés éveillés. Les otorhinolaryngologistes réalisent régulièrement une endoscopie nasale dans le cadre de leur évaluation de patients, mais cette évaluation ne porte pas sur les mêmes cibles que les anesthésiologistes, et leur examen est souvent réalisé bien avant la chirurgie. L'endoscopie nasale réalisée immédiatement avant une intervention sur les voies aériennes peut nous aider à déterminer s'il existe des obstacles au positionnement prévu de la lame de laryngoscopie directe ou de vidéolaryngoscopie (par ex., une lésion à la base de la langue ou un kyste valléculaire), à la visualisation laryngée (par ex., un important œdème supraglottique ou un larynx déplacé), au passage du bronchoscope flexible ou de la sonde trachéale (par ex., une ouverture laryngée très rétrécie), à la ventilation au masque, ou à l'utilisation d'un dispositif supraglottique. La vidéolaryngoscopie éveillée peut également être utilisée pour réaliser une évaluation plus poussée des voies aériennes, tout en sachant qu'une pathologie située à la base de la langue pourrait nuire au positionnement optimal de la lame ou pourrait être traumatisée lors de la laryngoscopie.

La plupart des anesthésiologistes connaissent bien l'anatomie des voies aériennes supérieures telles que visualisées à travers un endoscope. On ne peut pas en dire autant en ce qui touche à l'évaluation préopératoire des lésions des voies aériennes via des images tomodensitométriques ou d'IRM. Dans l'idéal, de tels examens devraient être évalués en collaboration avec un radiologiste ou le chirurgien du patient afin de mieux interpréter l'emplacement et l'étendue de la pathologie obstructive. Dans ce numéro du Journal, El-Boghdadly et coll. rapportent l'utilisation d'un logiciel d'imagerie pour convertir des tomodensitomètres hélicoïdaux dans un format d'endoscopie virtuelle en trois dimensions (3D); ces images peuvent ensuite être utilisées pour offrir une vue intraluminale «au passage» (fly through) de l'anatomie supraglottique, glottique et sous-glottique, semblable aux images obtenues avec un bronchoscope flexible. ${ }^{6}$ Les auteurs ont évalué l'utilité de cette modalité en demandant à un échantillon aléatoire de leurs collègues d'indiquer leur prise en charge de dix scénarios : chaque scénario était présenté par une brève capsule clinique et un tomodensitomètre hélicoïdal standard. L'imagerie d'endoscopie virtuelle en 3D a ensuite été ajoutée à la capsule, et les prises en charge retenues ont alors été réévalués. La prise en charge proposée après l'ajout de ces images était plus prudente.

Dans la mesure du possible, il faudrait compléter l'évaluation standard des voies aériennes par une endoscopie nasale ou un examen des images tomodensitométriques ou IRM de tous les patients présentant une pathologie obstructive des voies aériennes connue ou soupçonnée, indépendamment de leurs signes et symptômes de présentation. En raison du conditionnement des muscles respiratoires, un patient souffrant d'une tumeur à croissance lente pourrait ne présenter que très peu de symptômes malgré une maladie obstructive avancée. De la même manière, chez un patient striduleux en raison d'une maladie laryngée obstructive plus aiguë, le stridor pourrait devenir moins évident au fur et à mesure que les muscles respiratoires se fatiguent. À l'occasion, il est possible qu'on doive renoncer à une évaluation approfondie des voies aériennes chez un patient souffrant d'une pathologie avancée ou symptomatique et nécessitant une intubation trachéale urgente, que ce soit par manque de temps ou parce que le patient ne peut supporter la position allongée sur le dos (ou même à moitié allongée) nécessaire à l'obtention d'images d'IRM ou de tomodensitométrie. Un examen endoscopique nasal pourrait toutefois encore être possible. Dans ce cas, il faut tenir compte du caractère incomplet de cette évaluation lorsqu'on planifie la prise en charge des voies aériennes. 
La mise au point d'un plan de prise en charge à partir des informations obtenues pendant l'évaluation des voies aériennes

Les résultats des évaluations standard et approfondie des voies aériennes sont utilisés pour décider des approches initiales et alternatives les plus sécuritaires pour intuber le patient. Une évaluation minutieuse d'un patient atteint de pathologie obstructive des voies aériennes pourrait indiquer que la prise en charge des voies aériennes peut être réalisée de façon sécuritaire après une induction intraveineuse de routine de l'anesthésie générale, facilitée par un bloc neuromusculaire. Cela présupposerait que, malgré la pathologie obstructive, l'évaluation indique que peu de difficultés sont anticipées pour la laryngoscopie directe ou la vidéolaryngoscopie (c.-à-d. le positionnement de la lame et l'exposition laryngée subséquente), la ventilation au masque, l'intubation trachéale ou le positionnement d'un dispositif extraglottique, ou suite à des problèmes physiologiques tels qu'un estomac plein ou une désaturation rapide anticipée à l'apnée. ${ }^{7,8}$ Dans l'étude de Rosenblatt, 114 des 138 (83\%) patients se présentant pour une chirurgie des voies aériennes - la plupart souffrant de lésions obstructives - ont pu être pris en charge en toute sécurité après l'induction. Cela étant dit, il faut souligner qu'une évaluation approfondie des voies aériennes par endoscopie nasale préopératoire a permis de minimiser les incertitudes et ainsi permis d'obtenir un tel résultat.

À l'autre extrême, une évaluation approfondie des voies aériennes pourrait indiquer que la meilleure façon d'obtenir le maintien de la perméabilité des voies aériennes serait une trachéostomie. Suite à l'endoscopie nasale, cette approche serait indiquée si l'ouverture laryngée était significativement réduite ou une pathologie rendait le larynx méconnaissable (c.-à-d. considérablement déplacé ou à un angle défavorable).

L'intubation orale ou nasale éveillée, ${ }^{9}$ tout comme l'intubation trachéale suivant l'induction de l'anesthésie générale par inhalation, ${ }^{10}$ ont été préconisées en cas de situations moins extrêmes mais tout de même difficiles, identifiées lors de la nasopharyngoscopie. Ces deux techniques ont affiché de bons résultats dans cette population, mais comme le remarque le NAP4, il y a également des échecs. ${ }^{1}$ Malheureusement, le NAP4, la NCEPOD et les études sur les réclamations réglées (closed claims) ne peuvent fournir de données pour établir le dénominateur de la population atteinte de pathologie obstructive des voies aériennes, ce qui rend complexe la comparaison directe entre le taux d'échec des intubations orales ou nasales éveillées et le taux d'échec de celles réalisées après une induction par inhalation.
L'induction par inhalation rend inutile la coopération du patient et, une fois réalisée, permet en théorie une laryngoscopie directe ou une vidéolaryngoscopie et le passage primaire d'une sonde endotrachéale (SET). Les avantages potentiels de cette modalité comprennent le maintien de la ventilation spontanée et un renversement rapide de l'hypnose en cas de difficultés d'intubation. Les risques de l'induction par inhalation comprennent des effets néfastes sur le tonus et la perméabilité des voies aériennes, ${ }^{12,13}$ qui pourraient rendre l'induction plus difficile et la prolonger en cas de pathologie obstructive des voies aériennes. En outre, si la perméabilité des voies aériennes est perdue, l'apnée associée à l'obstruction complète empêchera l'élimination de l'agent volatil, supprimant par conséquent son avantage de sécurité présumé de réveil rapide. Dans les 16 cas d'induction par inhalation présentés dans le rapport du NAP4, les voies aériennes ont été compromises dans 12 cas, et la ventilation spontanée a été perdue dans 11 cas. ${ }^{1}$ L'induction de l'anesthésie générale par inhalation chez un patient adulte atteint de pathologie obstructive des voies aériennes devrait en règle générale être réservée comme alternative pour les patients qui ne peuvent coopérer pour une approche éveillée.

L'intubation orale ou nasale éveillée est, en théorie, sécuritaire parce que le patient maintient la ventilation, la perméabilité des voies aériennes et la protection des voies aériennes pendant l'intubation. En outre, si l'on se sert d'un endoscope flexible, cela permettra de contourner les lésions obstructives situées à la base de la langue et servira de mandrin afin de guider la SET dans le larynx et la trachée. À l'inverse, une anesthésie topique optimale des voies aériennes pourrait s'avérer difficile à réaliser dans certains cas de pathologies obstructives des voies aériennes, et le passage d'un endoscope via une ouverture laryngée plus étroite pourrait être difficile ou mal toléré par un patient éveillé. De plus, des comptes rendus ont fait état d'une perte totale de la perméabilité des voies aériennes pendant une intubation éveillée causée tant par l'anesthésie locale en soi ${ }^{14-16}$ que par la sédation concomitante. ${ }^{17}$ Les données du NAP4 sur l'intubation orale ou nasale éveillée sont difficiles à interpréter. En effet, les 23 utilisations enregistrées d'une intubation par bronchoscope flexible regroupaient son utilisation chez les patients anesthésiés et chez les patients éveillés. Il y a eu 14 échecs, dont quatre seulement chez des patients éveillés. ${ }^{1}$

Il est donc clair que l'intubation éveillée et l'induction par inhalation peuvent échouer chez des patients atteints de pathologies obstructives des voies aériennes, mais le taux d'échec est inconnu. Cela veut dire qu'il faut disposer d'un plan de secours en cas d'échec dans le maintien de la prise en charge des voies aériennes pendant que l'oxygénation est maintenue ou lorsqu'on est confronté à une situation 
dans laquelle il est «impossible d'intuber, impossible d'oxygéner ». Le NAP4 fait clairement état de cas dans cette population où de multiples tentatives d'intubation trachéale ont mené à une situation 'impossible d'intuber, impossible d'oxygéner'. Ainsi, il est essentiel de minimiser les tentatives à répétition avec une même technique de façon à amorcer le plan de secours (par ex., la réalisation d'une trachéostomie éveillée après un échec d'intubation orale ou nasale éveillée) avant d'être confronté à un cas où il est 'impossible d'intuber, impossible d'oxygéner'. Le plan en cas de situation 'impossible d'intuber, impossible d'oxygéner' est encore plus crucial dans la population atteinte de pathologie obstructive des voies aériennes où une telle situation est plus probable. Le plan de secours retenu en cas de situation 'impossible d'intuber, impossible d'oxygéner' doit être complètement faisable, plutôt que de réaliser des voies aériennes chirurgicales d'urgence chez un patient obèse avec un cou induré ou précédemment irradié ou de retomber sur une oxygénation extracorporelle (ECMO) chez un patient apnéique. S'il n'y a pas de plan viable en cas de situation 'impossible d'intuber, impossible d'oxygéner', il faut envisager une trachéostomie éveillée sous anesthésie locale comme plan principal, ou, dans de très rares circonstances, d'établir en premier lieu une ECMO sous anesthésie locale.

La prise en charge optimale d'un patient atteint de pathologie obstructive localisée à la mi-trachée est controversée. Le maintien de la ventilation spontanée a été préconisé par certains, alors que d'autres recommandent une induction intraveineuse avec administration d'un bloc neuromusculaire. ${ }^{18}$

\section{La mise en ouvre du plan d'intubation chez un patient présentant une pathologie obstructive des voies aériennes}

Grâce aux informations tirées des évaluations standard et approfondie des voies aériennes, un plan rationnel peut être élaboré pour prendre en charge les voies aériennes de façon sécuritaire. Une exécution experte du plan est absolument cruciale chez un patient atteint de pathologie obstructive des voies aériennes. Fait intéressant, le panel d'experts réviseurs du NAP4 a évalué que seuls $30 \%$ des cas rapportés de pathologies au niveau de la tête et du cou avaient été mal pris en charge, ${ }^{1}$ ce qui suggère que, malgré un plan rationnel, des problèmes peuvent survenir pendant sa mise en œuvre. Il y a là un certain nombre d'implications. Premièrement, chez un patient en situation d'urgence, les voies aériennes doivent être rapidement dégagées et leur perméabilité assurée - c.-à-d. avant que l'obstruction complète ne devienne imminente et pendant que la coopération du patient permet encore une approche méthodique à l'intubation orale ou nasale éveillée ou à la trachéostomie éveillée. Deuxièmement, chez les patients chirurgicaux, en urgence ou non, présentant des voies aériennes fragilisées - étant donné que la perte des voies aériennes est toujours une possibilité pendant les tentatives d'intubation -, il faut que le matériel complet soit disponible et que le personnel nécessaire soient présents tout au long de la réalisation des plans d'intubation principal et alternatif et des plans de prise en charge en cas d'impossibilité d'intuber, impossibilité d'oxygéner, afin de faciliter des transitions rapides et en douceur si nécessaire. ${ }^{19} \mathrm{Si}$ une cricothyrotomie d'urgence est le plan de secours, la position de la membrane cricothyroïdienne (MCT) doit être déterminée et marquée sur la peau au préalable, les études existantes indiquant le faible taux de réussite de la localisation de la MCT par palpation seulement. ${ }^{20-22}$ Ainsi, si le temps le permet, une échographie doit être réalisée pour localiser la MCT. ${ }^{23} \mathrm{La}$ liste de vérification de sécurité préopératoire (time-out) doit présenter à l'équipe les techniques d'intubation primaire et alternative planifiées, ainsi que le plan en cas de situation 'impossible d'intuber, impossible d'oxygéner'. Il faut également spécifier les déclencheurs pour l'amorce du plan d'intubation alternatif ou du plan en cas de situation 'impossible d'intuber, impossible d'oxygéner'. Dans l'idéal, tout le personnel en salle devrait avoir le droit d'indiquer à voix haute la survenue de ces déclencheurs afin d'éviter une fixation inappropriée sur une seule technique.

En cas d'intervention éveillée sur les voies aériennes d'un patient atteint de pathologie obstructive des voies aériennes (c.-à-d. de trachéostomie éveillée ou d'intubation orale ou nasale éveillée), le positionnement du patient en position assise ou semi-allongée améliorera son confort et donc sa coopération pour l'intervention. L'Heliox, un mélange à faible densité d'hélium et d'oxygène, facilitera sa respiration, ce qui aura également un impact favorable sur son confort et sa coopération. De l'oxygène d'appoint peut être administré, mais, lorsqu'il est utilisé conjointement à l'Heliox, il diluera cet agent et réduira son efficacité. Le monitorage du $\mathrm{CO}_{2}$ de fin d'expiration permettra de confirmer le maintien des échanges gazeux au cours d'une intervention éveillée.

Deux raisons peuvent justifier de renoncer à la sédation d'un patient éveillé présentant des voies aériennes fragilisées. La première est que certains agents ont des effets néfastes sur le tonus des voies aériennes ou l'effort respiratoire. ${ }^{12} \mathrm{La}$ seconde raison est qu'il peut s'avérer utile que le patient puisse obéir rapidement à des ordres pour réaliser une anesthésie topique des voies aériennes puis procéder à une intubation à l'aide d'un endoscope flexible. En demandant au patient d'inspirer pendant l'insertion de l'endoscope flexible, l'épiglotte s'élèvera; 
si l'on demande au patient de renifler, cela permet d'ouvrir les cordes vocales afin de faciliter le passage de l'endoscope ou de la sonde trachéale via la glotte. Chez un patient présentant un œdème supraglottique important, le seul indicateur de l'emplacement de l'ouverture glottique sera souvent le mouvement des tissus œdémateux pendant la respiration et l'apparition de bulles durant l'expiration. Une sédation pharmacologique judicieuse peut être un bon complément aux mots de réconforts destinés à calmer et rassurer le patient.

La prise en charge optimale du patient présentant une ouverture laryngée lésée consiste souvent en une trachéostomie éveillée; toutefois, si l'intubation endoscopique orale ou nasale éveillée est la méthode retenue, il faut porter une attention particulière aux détails de passage de l'endoscope et de la SET. L'utilisation d'un endoscope et d'une SET de plus petit diamètre pourrait être préférable, bien que cela puisse potentiellement compromettre la manœuvrabilité de l'endoscope. Il convient d'avertir le patient qu'il est possible qu'il ne puisse momentanément pas respirer pendant le passage de l'endoscope ou de la SET. Il pourrait alors être utile de lui demander de faire un bref «test d'apnée » afin de lui prouver qu'il est capable de tolérer de retenir brièvement son souffle. Le passage de l'endoscope et de la SET, et le retrait subséquent de l'endoscope de la SET, doivent être réalisés rapidement. Une vidéolaryngoscopie éveillée peut également être utilisée chez un patient sous anesthésie topique présentant une ouverture laryngée lésée afin de faciliter le premier passage d'une petite SET, ce qui évite de devoir faire passer l'endoscope, une manœuvre qui peut être mal tolérée. Un compte rendu récent a détaillé l'utilisation réussie d'une nouvelle SET à ballonnet, de 2,4 $\mathrm{mm}$ de diamètre interne et de $40 \mathrm{~cm}$ de long, en conjonction avec le respirateur à commande manuelle Ventrain ${ }^{\circledR}$ (Ventinova Medical B.V., Eindhoven, Pays-Bas) ${ }^{24,25}$ chez une série de patients chirurgicaux, dont certains présentaient une ouverture laryngée gravement compromise. ${ }^{26}$ Cette combinaison est prometteuse pour certains patients, chez lesquels la trachéostomie éveillée ne serait alors plus nécessaire; des études supplémentaires sont toutefois nécessaires pour le confirmer.

Enfin, si l'évaluation standard et approfondie des voies aériennes suggère qu'une induction intraveineuse avec un bloc neuromusculaire est justifiée, il est toutefois important de faire les préparatifs nécessaires à parer aux difficultés, notamment de s'assurer de la disponibilité de matériel pour réaliser les techniques d'intubation initiale et alternative, d'un dispositif supraglottique calibré pour le patient, et de porter attention à la préoxygénation et à l'administration d'oxygénation apnéique pendant les tentatives de laryngoscopie et d'intubation trachéale. ${ }^{27,28}$ Comme toujours, la MCT doit être identifiée et marquée, le matériel pour ouvrir des voies aériennes chirurgicales d'urgence doit être à portée de main, et une personne doit être désignée pour réaliser une ouverture chirurgicale des voies aériennes rapidement, si nécessaire.

Indépendamment de la technique initiale retenue, l'expertise dans son exécution est cruciale pour tout patient atteint de pathologie obstructive des voies aériennes. Les anesthésiologistes doivent rechercher (et non éviter) les occasions de réaliser des intubations orales ou nasales éveillées dans des situations moins pressantes afin d'atteindre et de maintenir une expertise dans ces interventions. Les subtilités pour maximiser le confort du patient et réussir une technique ne s'acquièrent qu'avec l'expérience.

\section{L'optimisation de l'évaluation des voies aériennes : quelles sont les étapes au niveau du système?}

L'évaluation approfondie des voies aériennes est la première étape vitale lorsqu'on a affaire à une pathologie obstructive des voies aériennes. En tant que telle, elle nécessite des interventions et des compétences qui ne font pas partie de la pratique quotidienne de l'anesthésiologiste moyen. L'endoscopie nasale peut être réalisée à l'aide d'un nasopharyngoscope dédié ou d'un autre endoscope flexible de petit calibre. L'anesthésie topique de la muqueuse nasale est facile à atteindre. Dans notre institution, les résidents en anesthésiologie réalisent en moyenne une centaine de nasopharyngoscopies au cours d'un stage d'un mois sous la supervision d'un otorhinolaryngologiste surspécialisé en voies aériennes, et ils doivent être évalués sur dix interventions observées dans le cadre de leur formation obligatoire. Nos résidents nous ont par ailleurs fait part - de manière informelle - de leur grande satisfaction face à cette expérience. Alors que la résidence en anesthésie fondée sur les compétences doit devenir la norme, il serait peut-être judicieux d'envisager de faire de cette intervention une compétence fondamentale.

Qu'en est-il de l'endoscopie virtuelle 3D des voies aériennes? Cette technologie est-elle accessible au clinicien moyen? Afin de répondre à cette question, nous avons téléchargé la version d'essai du logiciel OsiriX (Pixmeo SARL, Bernex, Suisse) que El-Boghdadly et coll. décrivent dans la section de méthode de leur étude. ${ }^{6}$ Nous avons ensuite entrepris d'obtenir des données DICOM (pour Digital Imaging and Communications in Medicine, soit 'Images et communications numérisées en médecine') d'images tomodensitométriques hélicoïdales anonymisées, en faisant le décompte du temps et des efforts nécessaires. Après $46 \mathrm{~min}$ au téléphone au cours de quatre conversations téléphoniques à trois départements et 24 
échanges de courriels avec cinq personnes différentes sur trois jours, nous sommes parvenus à obtenir un fichier DICOM compatible avec le logiciel OsiriX. Malheureusement, la version d'essai gratuite du logiciel ne pouvait pas prendre en charge la fonction d'endoscopie 3D nécessaire à la visualisation 'au passage' décrite dans l'étude de El-Boghdadly. Nous avons donc communiqué électroniquement avec la société pour confirmation mais n'avons pas reçu de réponse - et c'est là que nos efforts ont cessé. Avec ou sans l'utilisation de cette technologie potentiellement utile, le temps le permettant, il serait probablement de bonne pratique de passer en revue toute image tomodensitométrique ou d'IRM récente de patients atteints de pathologie obstructive des voies aériennes avec un radiologiste ou le chirurgien en charge.

\section{Conclusion}

Comme le décrivait le NAP4 et la NCEPOD, un patient se présentant avec une pathologie obstructive des voies aériennes court un risque pendant le processus de prise en charge des voies aériennes. Toutefois, ce risque peut être minimisé en optimisant l'évaluation standard des voies aériennes de ces patients grâce à des examens supplémentaires tels qu'une nasopharyngoscopie diagnostique ou des images tomodensitométriques ou d'IRM. L'anesthésiologiste et le chirurgien en charge peuvent se servir de ces informations pour engager une discussion réfléchie et s'entendre sur des plans principaux et de secours pour la prise en charge des voies aériennes et de l'anesthésie pour un cas partagé de voies aériennes. Espérons qu'en portant l'attention due à ces facteurs, nous assisterons à des améliorations notables dans le prochain rapport sur la morbidité et la mortalité liées à la prise en charge des voies aériennes des patients atteints de pathologies obstructives des voies aériennes.

Conflicts of interest None declared.

Editorial responsibility This submission was handled by Dr. Philip M. Jones, Associate Editor, Canadian Journal of Anesthesia.

Conflit d'intérêt Aucun.

Responsabilité éditoriale Cet article a été traité par Dr Philip M. Jones, rédacteur adjoint, Journal canadien d'anesthésie.

\section{References}

1. Patel A, Pearce A, Pracy P. Head and neck pathology. In: Cook T, Woodall N, Frerk C (Eds). 4th National Audit Project of the Royal College of Anaesthetists and the Difficult Airway Society. Major complications of airway management in the United
Kingdom. Report and Findings. London: Royal College of Anaesthetists and the Difficult Airway Society; 2011: 143-54.

2. Hoile R. Head and neck surgery. In: Gray AJ, Hoile RW, Ingram GS, Sherry KM, editors. The Report of the National Confidential Enquiry into Perioperative Deaths 1996/1997. London: National CEPOD; 1997. p. 25-37.

3. Norskov AK, Rosenstock CV, Wetterslev J, Astrup G, Afshari A, Lundstrom LH. Diagnostic accuracy of anaesthesiologists' prediction of difficult airway management in daily clinical practice: a cohort study of 188064 patients registered in the Danish Anaesthesia Database. Anaesthesia 2015; 70: 272-81.

4. Diaz-Gomez JL, Satyapriya A, Satyapriya SV, et al. Standard clinical risk factors for difficult laryngoscopy are not independent predictors of intubation success with the GlideScope. J Clin Anesth 2011; 23: 603-10.

5. Rosenblatt W, Ianus AI, Sukhupragarn W, Fickenscher A, Sasaki $C$. Preoperative endoscopic airway examination (PEAE) provides superior airway information and may reduce the use of unnecessary awake intubation. Anesth Analg 2011; 112: 602-7.

6. El-Boghdadly K, Onwochei DN, Millhoff B, Ahmad I. The effect of virtual endoscopy on diagnostic accuracy and airway management strategies in patients with head and neck pathology: a prospective cohort study. Can J Anesth. 2017; 64. DOI: 10.1007/s12630-017-0929-6.

7. Law JA, Broemling N, Cooper RM, et al. The difficult airway with recommendations for management-part 2-the anticipated difficult airway. Can J Anesth 2013; 60: 1119-38.

8. Rosenblatt WH. The Airway Approach Algorithm: a decision tree for organizing preoperative airway information. J Clin Anesth 2004; 16: 312-6.

9. Ovassapian A, Tuncbilek M, Weitzel EK, Joshi CW. Airway management in adult patients with deep neck infections: a case series and review of the literature. Anesth Analg 2005; 100: 585-9.

10. Mason RA, Fielder $C P$. The obstructed airway in head and neck surgery. Anaesthesia 1999; 54: 625-8.

11. Peterson GN, Domino KB, Caplan RA, Posner KL, Lee LA, Cheney $F W$. Management of the difficult airway: a closed claims analysis. Anesthesiology 2005; 103: 33-9.

12. Hillman DR, Platt $P R$, Eastwood $P R$. The upper airway during anaesthesia. Br J Anaesth 2003; 91: 31-9.

13. Nouraei SA, Giussani DA, Howard DJ, Sandhu GS, Ferguson C, Patel A. Physiological comparison of spontaneous and positivepressure ventilation in laryngotracheal stenosis. $\mathrm{Br} \mathrm{J}$ Anaesth 2008; 101: 419-23.

14. Liistro G, Stanescu DC, Veriter C, Rodenstein DO, D'Odemont $J P$. Upper airway anesthesia induces airflow limitation in awake humans. Am Rev Respir Dis 1992; 146: 581-5.

15. White AN, Wong DT, Goldstein CL, Wong J. Cervical spine overflexion in a halo orthosis contributes to complete upper airway obstruction during awake bronchoscopic intubation: a case report. Can J Anesth 2015; 62: 289-93.

16. Ho AM, Chung DC, To EW, Karmakar MK. Total airway obstruction during local anesthesia in a non-sedated patient with a compromised airway. Can J Anesth 2004; 51: 838-41.

17. McGuire $G$, el-Beheiry $H$. Complete upper airway obstruction during awake fibreoptic intubation in patients with unstable cervical spine fractures. Can J Anesth 1999; 46: 176-8.

18. Cook TM, Morgan PJ, Hersch PE. Equal and opposite expert opinion. Airway obstruction caused by a retrosternal thyroid mass: management and prospective international expert opinion. Anaesthesia 2011; 66: 828-36.

19. Law JA, Broemling N, Cooper RM, et al. The difficult airway with recommendations for management-part 1-difficult tracheal intubation encountered in an unconscious/induced patient. Can J Anesth 2013; 60: 1089-118. 
20. Law JA. Deficiencies in locating the cricothyroid membrane by palpation: we can't and the surgeons can't, so what now for the emergency surgical airway? Can J Anesth 2016; 63: 791-6.

21. Hiller KN, Karni RJ, Cai C, Holcomb JB, Hagberg CA. Comparing success rates of anesthesia providers versus trauma surgeons in their use of palpation to identify the cricothyroid membrane in female subjects: a prospective observational study. Can J Anesth 2016; 63: 807-17.

22. Lamb A, Zhang J, Hung $O$, et al. Accuracy of identifying the cricothyroid membrane by anesthesia trainees and staff in a Canadian institution. Can J Anesth 2015; 62: 495-503.

23. Kristensen MS, Teoh WH, Rudolph SS. Ultrasonographic identification of the cricothyroid membrane: best evidence, techniques, and clinical impact. Br J Anaesth 2016; 117(Suppl 1): i39-48.

24. de Wolf MW, Gottschall R, Preussler NP, Paxian M, Enk D. Emergency ventilation with the Ventrain ${ }^{\circledR}$ through an airway exchange catheter in a porcine model of complete upper airway obstruction. Can J Anesth 2017; 64: 37-44.

25. Lang SA. Emergency airway management: what are the roles for surgical cricothyroidotomy and the Ventrain ${ }^{\circledR}$ device? Can $\mathrm{J}$ Anesth 2016; 63: 997-8.

26. Kristensen $M S$, de Wolf MW, Rasmussen $L S$. Ventilation via the $2.4 \mathrm{~mm}$ internal diameter Tritube ${ }^{\circledR}$ with cuff - new possibilities in airway management. Acta Anaesthesiol Scand 2017. DOI:10. 1111/aas.12894.

27. Wong DT, Yee AJ, Leong SM, Chung F. The effectiveness of apneic oxygenation during tracheal intubation in various clinical settings: a narrative review. Can J Anesth 2017; 64: 416-27.

28. Patel A, Nouraei SA. Transnasal Humidified Rapid-Insufflation Ventilatory Exchange (THRIVE): a physiological method of increasing apnoea time in patients with difficult airways. Anaesthesia 2015; 70: 323-9. 